\title{
A New Narrative for the Future: Learning, Social Cohesion and Redefining "Us"
}

\author{
Marjo Kyllönen
}

\section{Why Do We Need a New Narrative for Our Schools?}

Do we need to rethink our education system, our schools and their functions? Do we need a new narrative for our schools? This chapter will begin by briefly exploring societal changes that are impacting schools, and then analyse the living environments of today's children and what they might look like in the future. The focus of this chapter is the social and cultural dimensions of sustainability and the crucial role our schools play in enabling these processes. For our schools and broader education systems to be successful in contributing to sustainable well-being, a holistic picture of the challenge is needed-one that develops an understanding of a changing environment and society because these dynamic domains fundamentally challenge the current education system. It is clear that if our schools are oblivious to these changes and challenges, they will lose their power and value to society.

Massive change in every domain is challenging the current school system and its structures. Technology has historically been one of the core

\footnotetext{
M. Kyllönen $(\square)$

Head of Education Service Unit, Education Sector, Helsinki, Finland e-mail: Marjo.kyllonen@hel.fi

(C) The Author(s) 2019

J. W. Cook (ed.), Sustainability, Human Well-Being, and the Future of Education, https://doi.org/10.1007/978-3-319-78580-6_10
} 
factors defining education systems because new technologies change the way we act, think, communicate and socialise, yielding an enormous impact on everyday life. The development of new technologies is exponential and its impact unpredictable (OECD 2016). And digitalisation is already rapidly changing our environments, procedures of communication and work. The flow of information is overwhelming; it is everywhere accessible to virtually everyone.

Artificial intelligence, robots and machine learning are improving and replacing the livelihoods of traditional middle class workers and are poised to replace even non-routine expert work. While this digital transformation is largely beneficial to mankind, there are some challenges to overcome. For instance, artificial intelligence can help solve complex problems. But as machines become more intelligent, they can easily replace human labour; ordinary skills are already being replaced by robots and automation (Brynjolfsson and McAfee 2014; Forecast 4.0 2015). The impacts will be widespread, but it seems clear already that young adults will not enter into linear career pathways; their working lives will resemble a mosaic of experiments and increasing career mobility. This will require a readiness to engage in dynamic and continuous lifelong learning processes and adaptability to a changing environment (Forecast 3.0 2012; Forecast 4.0 2015).

At the same time, the sharing economy and maker movement are also leading to a more open culture of distributed assets; resources owned by communities rather than individuals or institutions. As communities become ever more networked, new forms of arranging capital and services are evolving to meet the needs of local actors and are leading to greater local control of these services.

Even so, one of the challenges brought about by digitalisation is increasing inequality and in the future, inequality seems poised to worsen. How will working age populations adjust to a reality where routine work no longer exists? Is society ready for this rupture from the past, and how about schools? Will digitalisation lead to polarisation where there are those that have access to all and those that are marginalised? Whatever the answers, an imperative for schools must be equity, providing all children with the ability and skills to navigate the digital world. Critical thinking, the ability to evaluate, validate and sort information, detecting and managing online risks such as fake news among other skills are key to navigating this future. 
There is of course a threat that highly motivated children reap the greatest advantages of digitalisation while less fortunate students will fall increasingly behind (Brynjolfsson and McAfee 2014; OECD 2016). But perhaps, digitalisation also provides some solutions to its risks: formal education is likely to evolve with technology to be more fluid, a network of structures and education services offered in a customised, localised manner that meets the needs of individual communities and learners. By optimising and customising learning paths for learners, collaboration will be cultivated leading to new learning innovations (Bauman 2000).

Digital solutions, the use of new algorithms and artificial intelligence, enables flexible and personalised approaches to learning while the web opens almost unlimited opportunities for learners to gain new competences and skills. The role of formal education and especially formal degrees is likely to diminish as the required competencies for working life continuously change, especially since artificial intelligence is already replacing human decision making. Mastery can be achieved in multiple ways, both through accredited and non-accredited sources. If the public education system fails to respond these demands, learners (families and students) will seek alternative solutions. This ability to choose to opt in or out of traditional learning structures could accelerate polarisation in society and inequality in education (Forecast 3.0 2012). For public schools to be successful in the future, especially in the Nordic countries, new arrangements such as public-private partnerships may need to be created to ensure that high quality education services will be available for each and everyone in the future regardless of their background.

Increasingly, we see multiple possibilities to connect in a more flexible way with other learners in multidimensional and flexible networks. This is both a positive development and at the same time a threat. As the virtual world opens new possibilities for interaction, simultaneously people can become isolated or be sub-grouped, atomised and excluded from the society (Bauman 2000; Forecast 4.0 2015). The question for educators is, are we ready for these changes? What is the role of education, if in the near future artificial intelligence could replace most of the transmission of knowledge currently done by teachers?

Globalisation is affecting all areas of life and impacting our ways of living. Our daily environments are more complex and multicultural 
and local problems become global (the global financial crisis of 2008 is a prime example). People move freely across countries and our communities are ethnically, linguistically and culturally more diverse than ever. We face global challenges - such as climate change, migration, economic integration, rising inequality, all of which require global solutions. These political, environmental and economic wicked problems do not stop at national borders and can't be solved by individual people or nations, or tackled by using traditional approaches. Raising inequality requires a new approach to economic policymaking but also a new, deeper vision of social justice and cohesion. Increasing economic polarisation and unemployment combined with environmental volatility requires new approaches in education as well, and may be one of the plausible causes for redefining the purpose of education. Tackling these challenges requires collaborative approach, crossdisciplinary thinking creativity and brave actions (Forecast 4.02015 ; OECD 2016).

The change in demographics and global migration brings greater ethnic, linguistic and cultural diversity to our communities. Harmonisation of diverse values and global integration are fundamental challenges for populations whose identity is largely defined locally. However, these are critical challenges that must be addressed in order for individuals and communities to be successful in the future. These global demographic and migration trends amplifying diversification are not happening in isolation, but are connected to each other.

We are living in an era of accelerating change. The world has become more unpredictable and change is exponential. One consequence of this is that we really cannot predict the future-but we can imagine it and ask leading questions such as "what if"? We can look for signals and try to understand the drivers of change and societal transformation that will affect everything, especially teaching and learning (Dalin and Rust 1996; Forecast 4.0 2015). The current education model in the West was designed for the needs of an industrial era, a time of mass production and specific professions. Obedience and basic dexterity alone were a reasonable competence for the time of Spinning Jenny-style technology. This world does not exist anymore. But if we look at the average classroom, the design of the school has remained almost unchanged! The crucial question is, are we truly aware of the demands and expectations this change will force on us? 


\section{What Is a School of the Future?}

Paraphrasing Buckminster Fuller: we can't predict the future, but we can make it. People, organisations, nations play a crucial role in defining what the world will be tomorrow. And this will not happen in vacuum. Our actions towards the future are always value loaded, based on the ideas we think are worth developing. They reflect the fundamental values and norms of our society. And the educational system must reflect the society we would like to inhabit in twenty or thirty years from now (Dalin and Rust 1996). That is why we cannot ignore what is happening in our schools today and how education systems are to be developed in the near future. This may sound like an exaggeration, but it is true: the future of our society lies in the hands of our schools and educators. The actions we take today are the stairways to tomorrow. So, it is a matter of choice: what do we want the future to be?

Changes in our environment are challenging our education systems in various ways. Education systems have always had various tasks in society such as to create responsible citizens, to provide individuals with skills and competencies needed in the future and to provide good and qualified workers for the labour market. But are these still the central aims of education in a changing world and if so, what will be the most important for the success of our societies? Education systems can be effective tools for driving desirable change in society and transforming society for the future. But to do so successfully, education systems must be valued and respected by society. That's why an essential question today is, do our schools and more broadly our education systems provide our young ones with the competencies needed for the future? And do children need to come to school to learn at all? Is it meaningful that they are there? If they are at school, how does that environment contribute to a sense of well-being when so much is uncertain?

Education has traditionally played an important role in preparing individuals to enter society and the market economy by providing them with the competences needed to participate in both arenas. However, this function comes into question in a world where knowledge is everywhere. Where does it leave our formal education? Can it equip our children with the competencies needed in the future society and also in working life? On top of these fundamental questions is the daily concern that learning must be meaningful for students. How can these competing interests be met? 
The traditional way of teaching where knowledge is fragmented is assuredly not relevant any more. The children that now are beginning their school careers will still be at the labour market in 2070. It is hard, if not impossible to predict what competencies will be needed for that era. To learn and be competent within one profession is no longer sufficient, even today. Therefore, the task of the education system must be to enable students to meet the future with flexibility and curiosity, motivation and competence to learn and they must be resilient in the face of change. Learning must make sense to students - they must understand why and for what purpose they are learning and how they will utilise these competencies and skills in everyday life. In order to do this, they must move from repeating or searching for information to an ability to evaluate and order information (Dalin and Rust 1996; Forecast 4.0 2015; Salmela-Aro et al. 2016).

We are at a turning point: it is time to rethink the role of our schools for a sustainable future. Practically, the world we must prepare our children for does not exist, yet still we have to provide students with the competencies they will need for a society that promotes well-being and sustainability. This is the dilemma facing educators, policy makers and parents. We will be forced to make decisions about virtually every aspect of education, subject-based curriculum, for instance. We know from experience that life is not split into subjects, yet we teach as if it is, which likely makes some problems worse. What a learner needs is a good quality learning process, where knowledge is built on the basis of different subjects and their knowledge structure, but taught in a holistic way.

What schools must do in this complex and multidimensional world is to provide children with a flexible mind, understanding and respecting every member of the society regardless of their backgrounds or capabilities (Adler 2002). Education is for the civilisation of nations-an independent value and task in society; it is what powers the next generation to become full members of society. Can we leave this task to the internet? Or do schools still have something to give to children? My answer is yes, and moreover, the role of the school in the future will be increasingly important in promoting sustainable lifestyles and attitudes that are essential to the well-being of our societies.

\section{Social Challenges, Well-Being and Education}

Education plays a crucial role in promoting well-being and sustainable development in Finnish society. And also, the well-being and participation of our pupils are the key factors for them to be successful in learning 
and reaching their potential. The well-being of society and the individual are intertwined in schools. The current Finnish concept of comprehensive education for all has been built on a strong vision of equality and equity that offered equal opportunities to every child irrespective of their background. Those behind this historical reform understood that for Finland to be successful in the future, the country cannot lose any potential that exists in its youth. And this founding principle remains strong today.

However, globalisation tends to accelerate polarisation: widening gap between rich and poor countries as well rich and poor individuals within a country. Finland has been among the most equal OECD countries in PISA research. Finland is an egalitarian welfare society and our education system is very egalitarian as well. Most of the children go to the neighbourhood school and the spatial segregation is considerably low compared to the USA (or other European countries). The learning gap in between the best and worst performing pupils is the smallest among OECD countries. The same is true for learning results between boys and girls (Bernelius 2013; OECD 2012).

In the fight against poverty, offering equal opportunities for every child to access good quality education is crucial. For the less privileged, the role of the school is central to promoting social, emotional and physical well-being as well as building civic and cultural literacy and skills. As is known, socio-economic background is one of the strongest factors shaping one's future across their lifespan. A good quality education can reduce the effect of social background and bring about equality and equity. To be a full and active member of the future society requires good self-esteem and self-confidence. This can be achieved only if children have an authentic experience of belonging and closeness (Dalin and Rust 1996; OECD 2016).

At the urban level, spatial segregation in Helsinki has been quite moderate compared to other European capitals (Vilkama et al. 2014). But there is a weak, but clear, signal of polarisation in the city: during the past years, Helsinki has experienced a similar urban polarisation development to other large Finnish cities similar to European and American contexts. Recent research indicates that this polarisation process is going on inside our cities as well. The most remarkable change has been how the population of immigrant pupils has been distributed in different parts of the city. In some schools, the population of non-native Finnish Speakers is around $50 \%$ and in some schools it is nearer to zero. And at the same time, deprivation seems to cluster. When we compare these 
statistics to the socio-economic background of families living in these neighbourhoods, they correspond with immigrant families and a lower social economical background. ${ }^{1}$ This differentiation of public schools in Helsinki and at the same time, the spatial socio-economic and ethnic segregation within the city is a fairly recent phenomenon as the city has had remarkably low-spatial segregation. Recent research points to a neighbourhood effect: pupils tend to have a higher level of attainment and express somewhat more positive educational attitudes in schools with a higher parental educational level and overall attainment level, regardless of the pupils' own family background (Bernelius 2013, Statistic City of Helsinki). It is a kind of vicious circle where the polarisation of the neighbourhood fosters the polarisation of the schools and vice versa. The performance gap between Helsinki's schools has grown, though the differentiation inside one school is still greater than in between schools.

There have been several actions at the Helsinki city level to tackle polarisation and segregation inside the city. For more than ten years, the city has had an active policy distributing more resources to those schools that are in neighbourhoods with greater need. Approximately 3 million euros per year has been delivered to 44 schools. The schools may decide how to use this resource: to hire more teachers, school assistants or to buy teaching and learning material, to organise school trips etc. The criteria for Positive Discrimination (PD) schools have been:

- An average level of education in the district

- The economic level of the families in the district

- Number of non-Finnish speakers in the school

- How "attractive" the school is: percentage of local residents who attend the school

There is a strong consensus and experience that supporting those districts that are facing more challenges than the others is an efficient tool to prevent dropouts. But the money is only part of the solution. The competence and attitudes of teaching staff and our leaders to work successfully with pupils of different backgrounds is fundamentally important.

The challenge of rising inequality requires a new emphasis on social cohesion and a new commitment not only locally but also globally. Education is the most powerful weapon to fight against inequality and to promote social awareness and responsibility, to promote well-being of all people, especially those coming from less privilege surroundings. 
In a diverse world, education can create a new sense of cohesion-a new concept of us, helping to define identity, instilling values and in this way also helping the integration of newcomers and migrants. Education can directly affect global trends by providing children with the competences and skills needed to build a more sustainable, just and successful future society (OECD 2016).

\section{Cultural and Ethnic Diversity in Our Environment}

Increasing immigration to Finland has made the country more ethnically and culturally diverse than ever before. Similarly, the number of international migrants has grown rapidly across OECD countries. This is challenging society to rethink the policies in the interest of multiculturalism. It is not a question of integration but moreover how do we create social cohesion and a new national identity that is socially cohesive. This does not require societies to merge; on the contrary cohesion can be achieved in a pluralist environment through constructive interaction and dialog. This is not an easy task as greater cultural, ethnic and religious plurality rises tension between different stakeholders (OECD 2016; Putnam 2015; Zetter et al. 2006).

Increasing diversity raises new challenges such as how to form new social cohesion at a time of increasing diversity and how to ensure that immigrant pupils achieve at the same level as their non-immigrant classmates. The challenge for the education community is to build a comprehensive, mutual understanding of $u s$; to form together the values of society, empower every newcomer, strengthen their identity and sense of belonging within society and stop radicalisation and tensions among groups (OECD 2016).

Schools must provide students with the skills of global citizenship and competencies such as cultural sensitiveness and awareness, co-operation and collaboration, understanding and acceptance of diverse cultural values. To be successful in cross-cultural adaption, we must understand that every culture is distinctive-their values, norms and beliefs that give meaning to individuals and societies. No culture is inherently better than the other; all cultures are equally valid and valued. And every one of us is culturally bound together to some extent (Adler 2002). The crucial question for the well-being of all members of society is how the school systems respond to increasing migration. 
In Finland, the environment has become more complex, multidimensional and multicultural than it was when the current Finnish model for basic education was invented. Finnish society, as well as Western Europe, has been quite homogenous leading to a shared understanding of $u s$, at least at a national level (Dalin and Rust 1996). Today, the cultural and ethnic background of pupils and families is more diverse than it was in the past.

Helsinki has been the capital of Finland since 1812. It has grown from a small town of 4000 people to a medium-large city of 600,000 inhabitants. Together with the surrounding cities, Espoo, Kauniainen and Vantaa, greater Helsinki forms a metropolitan area of 1.4 million inhabitants. Helsinki has grown rapidly during the past decade and 63\% of net migration gain has been non-native Finnish speakers (Tikkanen 2014; Vuori and Laakso 2015). However, in the beginning of 2015, only slightly more than $13 \%$ of the total city population had a foreign background $^{2}$ (Hiekkavuo et al. 2016). In the basic education system, $20 \%$ of all pupils in Helsinki's schools are non-native Finnish speakers. ${ }^{3}$ The amount of immigrant-background pupils has grown rapidly during the past years and it is predicted have a rapid growth also in the future (Statistics 2016). The statistics also show that young immigrants living conditions in many areas are poorer than their classmates ${ }^{4}$ (e.g. low income and unemployment) (Ranto et al. 2015). For our education system, the most challenging group are young people migrating to Finland at the age of 15-18 during or just after the last years of compulsory education. $^{5}$

The latest PISA-research result revealed that first- and secondgeneration immigrant students in Finland perform alarmingly worse than their non-immigrant classmates in problem solving, mathematics and literature, and by the end of their compulsory education, the immigrants were two years behind their non-immigrant classmates (OECD 2015; Harju-Luukkainen et al. 2014). What makes this result even more troubling is other recent research which shows that on average the Finnish language skills of the immigrant-background students was at a good level, especially among second-generation pupils (Kuukka and Metsämuuronen 2016). So the lower learning results can not merely be explained by not to having sufficient Finnish language skills. One of the factors that explained the learning differences was the socio-economic background of the pupils. When we combine this result with the fact that in many cases the immigrant-background childrens' living conditions are worse by many 
measures than by their classmates, we confront the real challenge of segregation.

With these indicators raising alarm, the question is how can we tackle this challenge? Is there something we could do today to address segregation and build a better, sustainable future? The dropout rate among immigrant-background young people is considerably high compared to their non-immigrant classmates. This can lead to a situation where exclusion from society is due to a pupil's background. This injustice can no longer be ignored. We must rethink our actions and education practices and understand that for a sustainable future, we must get to work building new sources of social cohesion and a new, shared understanding of us. In Finland, and much of the rest of the world, our challenge is how we can create a new understanding and cohesion out or the diversity and multiple identities we have in our societies.

As the amount of immigrant pupils has increased in Helsinki region, one of the city's challenges is how to promote inclusion of young people who immigrate to Finland and have virtually no formal educational background. The city's response has been to develop means of supporting immigrant students to become full and active members of the community. In Helsinki, like in the most of the biggest cities, traditionally the newly arrived migrant students (NAMS) must start their formal education in preparatory classes. They follow a specific curriculum for one year (under 10 years old $=900$ hours and over 10 years old $=1000$ hours). Preparatory classes are in different schools, but not always in the student's neighbourhood and thus pupils may need to travel to another school. But every pupil will have a personal learning plan based on their skills and needs that is written together with the teacher, parents and pupil. Though the objectives are set in the beginning of the preparatory year, they are flexible and can be modified as the pupil develops. Pupils in the preparatory classes integrate into the mainstream classes as soon as possible, usually first in the non-academic lessons like sports, art and music. However, this separation of learning environments may not be most beneficial to student performance.

The new Finnish National Curriculum for basic education emphasises the importance of inclusion and the right for every child to study with their classmates at a neighbourhood school (OPH 2014). These principles will be widely implemented, including for Helsinki's NAMS. Practically, this will mean that all the first and second grade NAMS will be integrated into mainstream classes. As of 2017, there are pilot projects 
in a few Helsinki schools and the early results are very promising. In this new approach, schools receive extra resources for each NAMS and are permitted to decide how to use it in the most efficient way to support students integrated into the mainstream group (e.g. hire more teachers, class assistant, etc.). When teachers work together in pairs or groups they have more flexible arrangements in the classroom and can support individual pupils better. Also in this model, every NAMS has a personal learning plan with personal objectives based on the skills they have. After one year of inclusive preparatory instruction, these pupils continue their studies with their classmates and then follow the basic education curriculum.

In Finland, school days are the shortest among OECD countries and there not many extracurricular activities that take place at school after the school day. For first graders and some second graders, municipalities provide afternoon activities to a maximum of five hours a day. But for older children, similar activities are not provided by the municipalities, leaving it to a parent's ability to enable after school activities for their children.

To be included in society, it is of the utmost importance to find your place. Find one's place includes seemingly minor things like access to activities after school hours. This has proved to be a crucial challenge among our immigrant pupils especially among those that have arrived to Finland at the age of $\mathbf{1 5}$ or above. Helsinki provides a rich recreational environment for youth, but a recent city survey showed that children and young people with lower socio-economic background utilise these possibilities far less than those from a higher socio-economic background.

To help our newly arrived immigrant pupils to find reasonable activities after school and thus prevent exclusion from the society, municipal education managers have started an intensive co-operation between schools that have older NAMS preparatory classes and the local youth centres. In this model, a youth worker comes to the school to work with teachers to develop different possibilities for the students to visit locations in the city and introduce them to new low cost hobbies. The aim is to support holistic integration and social inclusion of the student as well their family. The expertise of two different professions from two separate departments provides more holistic support for students and their families.

As often said, it takes a village to raise a child. But what are the villages of our time? And can a growing understanding of social well-being and belonging create a new type of cohesion in our society? Can schools foster a greater sense of community not only inside the school but also 
in families? Education is an effective instrument for lifting people out of poverty, but what are the incentives that are effective enough? If our schools do not understand their role in promoting well-being and social cohesion, they will fail in their most important role. After all, education creates societies.

\section{The Power of Education-Participation and Belonging}

Today, half of the world population lives in cities and it is predicted that by 2015 , seven out of ten people will be living in cities. Cities are the hubs for human capital, research, innovation and resources. They provide multiple employment opportunities and ways to move up the socio-economic ladder. But at the same time, cities tend to host high levels of poverty and exclusion from labour market and society in general. These difficulties can create isolation, tenuous networks and social alienation, lack of trust and violence (OECD 2016). Citizen's participation and involvement is a powerful tool to prevent exclusion. For cities, it must be a priority to build up and empower communities - to increase quality life and well-being for all the citizens.

People who have a real experience of participation, understand how they can influence society, they are active citizens. This experience tends to strengthen tolerance towards other people in a diverse environment. The societies that promote well-being and participation of its citizens work against marginalisation and exclusion and strengthen social cohesion (Putnam 2000; Pettit 2012). An individual is unlikely to have the experience of belonging if they are not at some level empowered. This is especially true for schools and their students. If we want to be successful in the future, we need to stretch ourselves into our surrounding community.

The diversity and flexibility of society are the key elements for successful and sustainable future. Diversity and flexibility creates resiliency that is needed to cope in a complex and unpredictable environment. But this is only true if there is a free flow of information and real collaborative networks. If the community is fragmented and subgroups are excluded, diversity becomes a hindrance instead of a source for further growth and success of the community. This can lead in its worst case to destructive conflicts (Capra 2009). The question then is how to lead diversity in a way that it promotes well-being and success of the community. How can policy makers, community leaders, schools and families involve and 
empower neighbourhoods so that everyone has an authentic experience of belonging and participation? First and foremost, in the context of education, this requires a deep understanding of school culture and the ability to develop it in a way that fosters everyone's participation and empowerment, especially those most marginalised.

Participation in society also requires strong involvement of public institutions and the opportunity and space, to become socially active. The role of the government and municipalities must be to create forums to encourage open discussion between the community and service providers (Mayan et al. 2013). In the city of Helsinki, participation of the citizens is one of the city's core values and strategies. Citizen involvement is a significant policy tool to promote well-being of all. Helsinki is also strongly emphasising the importance of participation of children and adolescents in a programme called Ruuti that engages all city departments and decision makers with youth. The programme is based on the belief that everyone should have and use their voice to influence everyday practices in their schools and government.

Youth participation is a key asset to promote active citizenship and social inclusion and thus prevent exclusion from the society. Helsinki's goal is that all youth will have a positive experience of democratic participation every year and thereby experience what it's like to make a difference by working towards a greater cause. As a matter of policy, young people are to be heard on issues affecting them, and their initiatives are taken seriously by the city. Their actions and initiatives will improve Helsinki and citizens' quality of life. The genuine experience of participation fosters a sense of belonging and intrinsic motivation because it enables young citizens to understand their agency and their power to make a difference.

\section{Social Cohesion and a New Definition of $U s$}

As stated above, the challenges of rising inequality require a new emphasis on social cohesion and a new commitment to address it, not only locally but also globally. Education is the most powerful weapon in the fight against inequality because it can promote social awareness and responsibility (OECD 2016). The Finnish education system has succeeded in solving multiple challenges that many other countries have not. Finland has been a model country for education and the design of our education system is unique. But we must rethink the role of our 
education system if we want to build a sustainable future. Our next most pressing challenge is the ethnic, cultural and language diversity present in our schools.

Collective identity is an imperative when examining the social change. It allows different actors to have a sense of belonging and links to other individuals and groups and thus creates a joint, collective experience (Mayan et al. 2013; OECD 2016). Schools form a natural seedbed for fostering social cohesion and a new definition of us. Pupils come to the school to learn and do things together-an opportunity that should be taken advantage of. Collaboration, social skills, social responsibility-the ability to work and build knowledge together with different learnersthese are the competencies and qualities that must be promoted at school.

How then to create social cohesion and a new definition of us? I believe this question is more current and crucial than ever, especially in the school system I manage. A new definition of us is built on a strong sense and understanding of who each of us are as individuals - our backgrounds, culture, language, and history. One cannot be a strong member of society before you know who you are and where you belong. For schools, this requires a deep understanding of school culture and the ability to develop it in a way that fosters everyone's participation and empowerment. I will come back to the importance of school culture and leadership later, but let's first look at social cohesion and the importance of identity.

Social cohesion is based on the willingness and capacity of people to co-operate with each other in a diverse environment. A socially cohesive society does not mean a society where all share the same values, beliefs and lifestyles - on the contrary, a socially cohesive society benefits from diversity (Stanley 2003). Society is shaping individuals at the same time that individuals are shaping society. This is a constant battle or a systemic circle of development and thus a process where-if we succeed-we can create a new concept of us, a new meaning who we are (Bauman 2000; Putnam 2015). Social cohesion does not mean identical values, but it is supported or nurtured by values such as equality, tolerance, freedom and respect for human rights. Co-operation and collaboration can nurture freedom, equality and respect for human rights (Larsen 2014; Stanley 2003).

Social cohesion and social outcomes are affecting each other. It is a systemic circle where one does not exist without the other. 
Social cohesion is about driving towards a more inclusive society where people have a sense of belonging and experience of authentic participation. The process is dependent on the willingness of the people; if they have an experience where they are not valued and treated equally, it will degrade their willingness to co-operate with others and thus diminished cohesion (Stanley 2003; UN DESA 2012). Zygmunt Bauman (2000) defines civility as "the ability to interact with strangers without holding their strangeness against them or without pressing them to surrender it or renounce some or all the traits that have made the strangers at the first place." This is the kind of civility school leaders, teachers and policy makers should promote in the everyday life of our schools. Assimilation is not the way to build up a successful future for our society. In a way, we all are strangers to each other, so there is no division but only shared experience. This requires a mutual understanding and respect. It is an ability that does not come for free. We must practise it-how to be in a fruitful interaction with strangers.

Modern society is a society of individuals. People want to go their own ways and not be disturbed. The rise of a hedonistic "me first" attitude is a phenomenon of the contemporary era. It seems increasingly clear that the growth of individualism is a threat to the public good and sense of community. Public space is now filled with private demands. There is a constant tension between the public good and an individual's wants (Bauman 2000; Kyllönen 2011). Individualism does not build societies. It points in the other direction, towards where everyone is responsible for their own future. This at the same moment, we need people who are willing to relearn the skills of true citizens. Schools can and should be the places where we teach our children trust and engagement in their own surroundings and societies, starting with their own classmates.

\section{The New Identity of “Us”}

All identities are constructed from various sources of history, culture, religion, geography and collective memory. Construction of one's identity is simultaneously an individual and social process and it is culturally rooted. Disjunctions or problems in the process of building up identity are linked in part to the difficulties of environmental change or disruption. We are living in an era, where our environment is more complex and unpredictable than ever before and the development of a durable 
individual identity is in danger. Not only have the teenagers felt insecure and fragmented but also the adults do (Castells 1997; Nuutinen 2015). The way we talk, the language we use is a powerful weapon for building societies or building walls-how we talk about and to others is crucial. Do we think that we are we or is there us and them (Castells 1997; Kegan and Lahey 2001)? Right now it is unclear, and that is why we need to build a new public narrative of $u s$.

The diversity of our environment challenges us to rethink and redesign our concept of $u s$. If we fail in this task, the consequences will be dramatic. Exclusion from the society-the sense of not belonging-can be the seedbed for radicalism and extremism. Finland has been quite a culturally and ethnically homogenous nation compared to other European states which may be a factor in the country's success (Castells and Himanen 2002).

Multiculturalism can bring about positive value for an equal society and for the construction of social harmony. But there can be a darker side too: multiculturalism policies can amplify "otherness." There is a tension between the ethnic identity and universal identity of citizens who share the values and norms of society (Prato 2009). A new identity of us can be constructed when we shift from additive programs tacked to the regular programme of studies focused on specific ethnic group to a holistic approach where the legitimacy of multiculturalism is no longer in question. The best strategy to accomplish this is to capture the best aspects of diversity (Dalin and Rust 1996). It is the formation of a new personality: a multicultural identity where people recognise simultaneously the similarities between all people and respect the diversity of humankind. They do not want to eliminate or assimilate the differences. Multiculturalism is a necessary outgrowth of the diversity and complexity of the twenty-first Century. In this respect, instrumentalising differences provides a pathway to a better future (Adler 2002; Hargreaves and Fink 2006). A multicultural personality has a flexible mind and evolves rapidly in a changing world. She or he has a capability to be adaptive and productive, even in ambiguous situations.

The new " $u s$ " is built on the diversity inherent in our environments. Our ethnic and cultural backgrounds are sources of both meaning and identity. To build a new concept of " $u s$," a new sense of social belonging and identity should not be the product of assimilation (the melting pot), but constructed from a new narrative of us that grows from the diversity of each community. In constructing a collective identity, it is important 
to celebrate what makes every person distinct. This gives the community a stronger sense of unity and balance because it allows differentiation inside the community. Collective identity also needs a vision at the state level-a national narrative-paired with an understanding of national well-being, otherwise the world of individual identities, where people are seeking their own well-being and prosperity will persist (Baumann 2000; Castells 1997; Castells and Himanen 2013).

The social construction of collective identity is always rooted in a context of relations and schools are communities where children can build a collective identity. Today, pupils should come to school to collaborate; an activity for which school leaders, teachers and policy makers must make time and space. Through collaboration, students will build strong relationships that can lead to a new concept of us. It is not a question of integration or assimilation, but moreover an interactive process of redefining identity together that is needed (Castells 1997; Nuutinen 2015; Prato 2009). Schools can be the starting point for a transformational project for constructing a new identity that can then scale towards the transformation of society.

A public narrative can construct both individual and collective identities. A shared narrative can also provide the motivation and courage to take decisions that lead towards a better, sustainable future. Marshall Ganz (2011) divides narratives into a story of self, a story of us and a story of now. The story of self is a story of our individual values and hopes. It is a construction of our own identity-who we are and what is unique about us. Social movements arise from new stories of $u s$; they are stories about organisation and interaction. The story of us is a community story of our shared values and goals. It is about telling a story that invites people to join together to be members of a community. The story of now asks people not only to join together, but also to take collective action. Collective stories are the most important and interesting because they tell us who we are relative to a larger community which can provide certainty in an unpredictable world in a way stories of self cannot. Organisations that lack the story of us also lack a shared identity. The story of us expresses the values of the organisation or community. It is a collective identity that enables us to communicate and collaborate with those inside the community. The us can take many forms: family, community, neighbourhood, organisation and nation (Ganz 2011; Kegan and Lahey 2001).

The story of now captures the challenge we are facing today in trying to build a sustainable future in the face of climate change. Hope seems to be 
increasingly fleeting as the climate crisis grows and global action remains marginal. A story of hope is needed, of how we can tackle the many crises confronting humanity. But in telling a story of hope, we must face the facts. As Ganz wrote in 2011, "hope is not to be found in lying about the facts, but in the meaning we give to the facts" (287). With hope, we need a strategy according to Ganz; a way to get from here to there. A way, that as a collective, we can overcome. This global collective will be born from a new identity of $u s$ that is as richly diverse as humanity itself.

\section{A New Narrative for the Future School}

As discussed above, the world has changed, but the narrative about the purpose of schools has not. And it is not sufficient to only make marginal corrections-a new story about our schools must be told as if the school was to be invented today. This must be a holistic story told not only by educators but also by all actors in society. It must be systemic in nature, not just aimed at narrow objectives such as academic achievement or labour force readiness.

The development of our school and education system for the future must proceed in a systemic and interactive process where society as a whole creates a framework for development of a school's operations and leadership. This process must determine the prerequisites for the development of schools, set the boundaries and ambitions, and critically, provide the resources necessary to achieve the vision. At the same time, schools today can work to bring about the change by influencing (updating) the perspectives on schools held by society (see Fig. 10.1).

External and internal factors define the possibilities and barriers for the development of a school. The outer boundaries of operations in a school are determined by societal development, the status and role of the school in the society and the nature of decisions made at both national and local levels. Inside the school, the opportunities for growth are tied to how the school develops as an organisation and opens up to the surrounding community. In general, a distributed approach to leadership is a critical success factor in the future school (Kyllönen 2011).

Schools are unusual, perhaps unique organisations-I struggle to name an analogue. Every organisation has its unspoken or unrecognised basic assumption such as "this is how we've always done business, this has been a successful way for us to solve problems" (Schein 1985). These basic assumptions sustain the organisation; after all, there is no need to "reinvent 


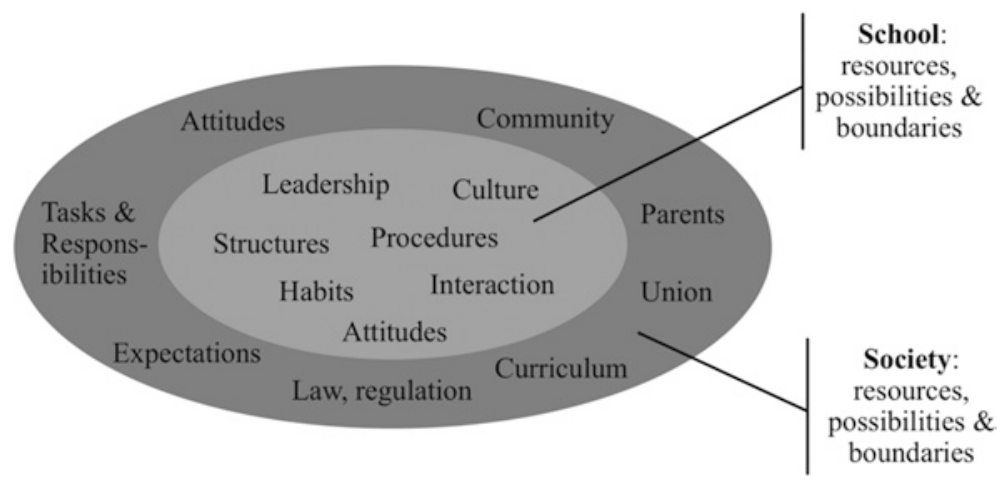

Fig. 10.1 The possibilities and boundaries for school development

the wheel". However, they can be dangerous expediencies-doing business as usual though the pattern of behaviour is no longer relevant. Schools are an organisation where all the members (teachers, principal, supporting staff) and even the customers (parents, students, society in general) have been raised by the organisation itself. We all have memories from our own histories in school about what makes a good or poor quality school. The problem today is that the world has changed and what was relevant in past does not meet the current and future needs of society.

To rewrite the narrative of the future school, a deep understanding of systemic change must be combined with the ability to make change at scale, not just marginal improvement (i.e. reform). To make a sustainable change to schools, it is critical to have a robust understanding of the school as a highly specific breed of organisation with unique structures, leadership, organisational culture and pedagogical implementation mechanisms as well as stakeholders vested in the organisation in uniquely personal ways (Fig. 10.2).

Archimedes said "Give me a lever long enough, and I can change the world". To change schools, effective leadership is the key factor; it is the lever that can make systemic change happen. We need leaders who understand the role of public education in creating a new definition of $u s$ which can be achieved in part through a process of creating a new narrative for the future school. However, leaders are not isolated on an island and do not make transformational change happen alone. Of equal importance is the organisational culture and its resistance to or readiness 


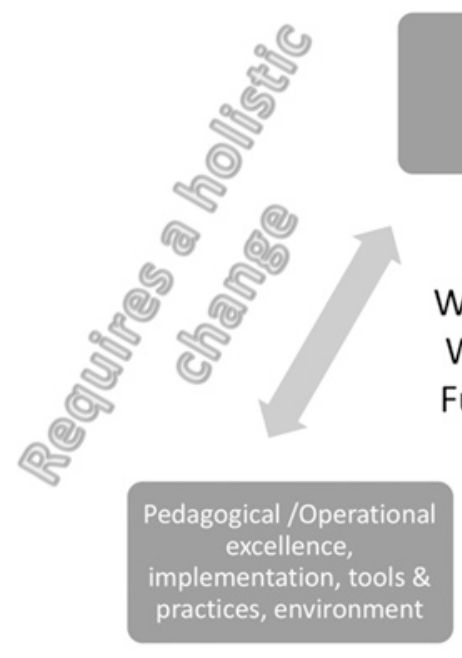

Leadership

Well-learning \&

Well-being for

Future Success

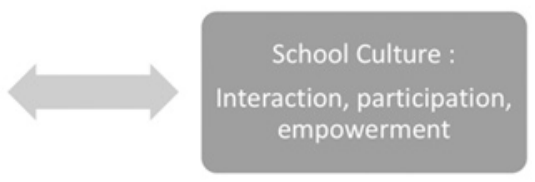

CKyllönen 2011/2015

Fig. 10.2 Key factors for the successful and sustainable change in the future

for renewal and change. It is a dynamic process where leaders create the conditions for changing operational culture and simultaneously the culture of school fosters further change (Fullan 2005).

A well-functioned school is a learning organisation. It is a living organisation that understands the urgent need to develop and change; to learn in order to be an organisation that stimulates the learning of its stakeholders. A successful school understands its role in the changing society today and has a vision for and of tomorrow (Dalin and Rust 1996; Hargreaves and Fink 2006). For too long, teachers were understood to be transmitters of knowledge. Today, they must form a collaborative community of professionals. This will be challenging for a profession that has a long history of autonomy. But collaboration is the key to taking a holistic approach to the work of the future school (Adler et al. 2008; Fullan 2005). Because this kind of collaboration will challenge existing structures, leadership must also come from teachers.

Leadership that is head, heart and hands is necessary to make change happen as Ganz (2011) suggested. The head is strategy: how to allocate resources to achieve desirable results or objectives. Heart overcomes the challenge of motivation: how to inspire people to act towards the 
greater good and have courage to take risks in order to make this change to happen. Hands is the ability to learn by doing - an opportunity especially relevant to teachers. Talented leaders can lead their organisation with narratives that give individuals a new definition of us-of belonging. Public narratives empower, help to construct identity as individuals, community and nations (Ganz 2011).

Wise leaders use their narratives in a way that it empowers their people, give vision and hope. They see the possibilities, the pitfalls and are able to lift their people to another level. Martin Luther King Jr. was just such a transformative leader who used powerful narratives that redefined us. He knew how to speak to people, how to lift them to act towards change. In a time when the American dream of equality regardless of racial, social or religious background was not available to everyone, he rose and shared his dream. He could have said "our reality is a nightmare" as it was being experienced by the marginalised, but he wanted people to believe in a better future and used his narrative wisely to suggest a way forward. This is the kind of leadership needed today, both national prominence of King, and also within the classroom (Ganz 2011; Kegan and Lahey 2001; King 1963) The way we talk, the narrative we tell affects the way we act and work. Narrative is not irrelevant, especially as we work to build a new society for the future.

We need a new public narrative to create social cohesion; a precondition essential for success of our society in the future. Public narrative is a tool to transform our values and our will into action to make choices for a better future. This starts with telling a new story of $u s$ that builds a new community of us. This happened in the 1960s when the people of Finland had the vision to offer equal opportunities for all and built an education system to deliver on that goal. The was a vision for the future-about the times we are living in now-and Finns had the collective courage to act accordingly despite resistance and prejudice. Are we now resting on the laurels of our past success? Yes. The world has changed and there is a now an urgent call for a new story of $u s$.

\section{Conclusion}

I strongly believe that our education systems are at a turning point and that it is past time to rethink the role and status of schools and our education system more broadly for today and the future. The current education system and its widely shared practices were designed for the 
needs of the industrial era; a time of mass production, routine work and narrowly defined professions. One only needs to look around to see that this world does not exist anymore. If education systems do not recognise this need for fundamental redesign, it may lose its value, power and role in society. To be successful in the future-to promote sustainability, well-being and well-learning-we must write a new narrative for our schools.

The world of today and tomorrow is more complex and more diverse than ever before. We must learn to respect diversity and similarity in new ways. The increasing diversity of our everyday lives challenges us to rethink and redesign our concept of $u s$. If we fail in this task, the consequences can be dramatic. Exclusion from society-the sense of not belonging — can be the seedbed for radicalism and extremism. To build a sustainable society, we must learn to think beyond ourselves, our own interests and understand what is right under these radically new circumstances.

For any nation to be successful in the future, the best way is to invest in good quality education system (this is the lesson Finland has learned over the last 60 years). Education that promotes social cohesion, equity and well-being for all citizens must be an organising principle. The success of the education system is strongly connected to the success of society as a whole in the case of Finland and many other countries

As Dalin and Rust wrote in 1996, "Yesterday's problems shape the present school" (30). By this logic, today's school cannot prepare students for the future. We urgently need a systemic change! Isolated actions will not be enough. We cannot make the change needed by correcting small problems. We need a holistic, systemic approach where schools and their functions are reflected in a larger context. School must become a societal organisation. It must be open to the surrounding society-and not only open but also in a productive, co-operative co-dependency.

For social, cultural, ecological and economic sustainable development, it is of utmost importance to learn and do things together. Social and societal learning can happen only when different learners and actors come together to share ideas and experiences with others in an open, productive way. The resiliency needed in the face of a complex, volatile environment can be achieved only in a society where diversity is understood to be a seedbed for the future success (Dyball et al. 2009). To be successful in the future, we must redefine the concept of us and 
thereby build a new identity of us that consists of all the diverse cultural, language and ethnic identities we see in our classrooms today. It is a process where we learn together in a fruitful interaction and discussion in an atmosphere of trust that recognises the value of all people.

What is the future for our schools and our societies? It is impossible to predict-but we can build it! There are problems and challenges that must be conquered-but at the same time, there are more opportunities and underutilised resources (witness the sharing economy) in our communities than ever before. The question now is, do we have the courage to take the right decisions and actions today to build a better future for our children? The actions for the future are never objective. Our values define our visions for the future, including and perhaps especially the future school. I believe that the role of the future school should be to create social cohesion in societies and promote well-being and participatory communities. This school will work to empower not only those who are working or learning at school but also the society as a whole.

Winnie the Pooh once said a very clever thing to Christopher Robin: "You're just in time for the best part of the day!" "And what time is that?" asked Christopher Robin. Winnie answered, "When you and me become we" (Geurs 2006).

\section{Notes}

1. Correlation lack of education and non-native Finnish speaking is remarkably high 0.83 .

2. People, who speak other mother tongues than Finnish or Swedish or Sami, the official languages of Finland.

3 . In $2015,17 \%$ of all the young people age $15-23$ have an immigrant background in Helsinki.

4. $45 \%$ of immigrant background minors.

5. All children living in Finland are subject to compulsory education that usually starts the year they'll be 7 years old and finish after 9 years of education, or the latest year they become 17 years old, Basic Act.

\section{REFERENCES}

Adler, P. (2002). Beyond Cultural Identity: Reflections on Multiculturalism. Retrieved April 2016, from http://www.mediate.com/articles/adler3.cfm.

Adler, P., Kwon, S., \& Heckscher, C. (2008). Professional Work: The Emergence of Collaborative Community. Organization Science, 19(2), 359-376. 
Bauman, Z. (2000). Liquid Modernity. Cambridge: Blackwell.

Bernelius, V. (2013). Eriiytyvät kapunkikoulut. Helsingin peruskoulujen oppilaspohjien erot, perheiden kouluvalinnat ja oppimistuloksiin liittyvät aluevaikutukset osana kaupungin eriytymiskehitystä. Tutkimukisa 2013. Helsingin kaupunki. Tietokeskus.

Brynjolfsson, E., \& McAfee, A. (2014). The Second Machine Age, Work, Progress and Prosperity in a Time of Brilliant Technologies. New York: W. W. Norton.

Capra, F. (2009). Foreword. In A. E. J. Wals (Ed.), Social Learning. Towards a Sustainable World. Principle, Perspectives and Praxis (pp. 14-15). The Netherlands: Wageningen Academic Publishers.

Castells, M. (1997). The Power of Identity (Vol. II). Cambridge, MA: Blackwell.

Castells, M., \& Himanen, P. (2002). The Information Society and the Welfare State. New York: Oxford University Press.

Castells, M., \& Himanen, P. (2013). Kestavan kansun malli. Globaalin kasvun malli. Valtioneuvoston julkaisuja22/2013.

Dalin, P. (1998). School Development. Theories and Strategies. An International Handbook. New York: Continuum.

Dalin, P., \& Rust, V. D. (1996). Towards Schooling for 21st Century. New York: Bloomsbury Publication.

Dyball, R., Brown, V. A., \& Keen, M. (2009). Towards Sustainability: Five Strands of Social Learning. In A. E. J. Wals (Ed.), Social Learning: Towards a Sustainable World (pp. 181-194). Wageningen: Wageningen Academic Publishers.

Forecast 3.0. KnowledgeWorks. (2012). Recombinant Education: Regenerating the Learning Ecosystem. http://www.knowledgeworks.org.

Forecast 4.0. KnowledgeWorks. (2015). The Future of Learning. Education in a Era of Partners in Code. http://www.knowledgeworks.org/sites/default/ files/forecast-4-future-learning-education-partners-code.pdf.

Fullan, M. (2005). Leadership and Sustainability. System Thinkers in Action. Thousand Oaks, CA: Corwin Press.

Ganz, M. (2008). What Is a Public Narrative? http://chutzpahportfolio.yolasite.com/resources/WhatIsPublicNarrative08.pdf.

Ganz, M. (2011). Public Narrative, Collective Action, and Power. In S. Odugbemi \& T. Lee (Eds.), Accountability Trough Public Opinion (pp. 273-289). Washington, DC: The World Bank. http://marshallganz.usmblogs.com/files /2012/08/Public-Narrative-Collective-Action-and-Power.pdf.

Ganz, M. (2013). Public Narrative. Self, Us \& Now (Worksheet). http:// marshallganz.usmblogs.com/files/2012/08/Public-Narrative-WorksheetFall-2013-.pdf.

Gardner, H. (2008). Five Minds for the Future. Boston: Harward Business Press.

Geurs, K. (Director). (2006). Pooh's Grand Adventure-The Search for Christopher Robin (Motion picture on DVD). USA, Walt Disney Home Entertainment. 
Hargreaves, A., \& Fink, D. (2006). Sustainable Leadership. San Francisco, CA: Jossey-Bass.

Harju-Luukkainen, H., Sulkunen, S., Suni, M., \& Vettenranta, J. (2014). Avaimet osaamiseen ja tulevaisunteen. Selvitys maahanmunttajataustaisten nuorten osaamisesta ja siihen liittyvistä taustatekijöistä PISA 2012 -tutkimuksessa. Koulutuksen tutkimuslaitos.

Helsingin kaupunki. (2016). Nuorten hyvinvointikertomus. http://www. nuortenhyvinvointikertomus.fi.

Hiekkavuo, A., Haapamäki, E., Ranto, S., Salorinne, M. (2016). Statistics 2016:2. Population with Foreign Background in Helsinki. City of Helsinki, Urban Facts. http://www.hel.fi/hel2/tietokeskus/julkaisut/pdf/16_01_15_ Tilastoja_2_Hiekkavuo_Haapamaki_Ranto_Salorinne.pdf.

Illich, I. (1970/1972). Deschooling Society (3rd ed.). London: Marion Boyars.

Jenson, J. (1998). Mapping Social Cohesion (CRP Study No. 7/03). Ottawa: Renou Publishing.

Kegan, R., \& Lahey, L. (2001). How the Way We Talk Can Change the Way We Work: Seven Languages for Transformation. San Francisco, CA: Jossey-Bass.

Kilpi-Jakonen, E. (2012). Does Finnish Educational Equality Extend to Children of Immigrants? Examining National Origin, Gender and the Relative Importance of Parental Resources. Nordic Journal of Migration Research, 2(2), 167-181.

King, M. L. (1963). I Have a Dream Speech. 28 August 1963, at the Lincoln Memorial, Washington, DC. https://goo.gl/QmKOsH.

Kuukka, K., \& Metsämuuronen, J. (2016). Perusopetuksen pä̈̈ttövaiheen Suomi toisena kielenä (S2)- oppimäärän oppimistulosten arviointi 2015. Kansallisen koulutuksen arviointikeskus. Julkaisut 13:2016. Tampere: Juvenes PrintSuomen Yliopistopaino oy.

Kyllönen, M. (2011). Tulevaisuuden koulu ja johtaminen. Skenaariot 2020 luvulla. Acta Universitatis Tamperensis 1678. Tampere: Tampere University Press.

Larsen, C. A. (2014). Social Cohesion: Definition, Measurement and Developments. http://www.un.org/esa/socdev/egms/docs/2014/ LarsenDevelopmentinsocialcohesion.pdf.

Mayan, M., Turner, A. T., Ortiz, L., \& Mofatt, J. (2013). Building a Multicultural Coalition: Promoting Participation in Civic Society Among Ethnic Minority Communities. CES, 45(1-2), 157-178.

Mintzberg, H. (1983). Structure in Fives. Designing Effective Organization. Englewood Cliffs, NJ: Prentice-Hall.

Nuutinen, P. (2015). Nuoret - koulu - tulevaisuus. Taivutuksia "notkan modernin” tapaan. In J. Enkenberg, E. Savolainen, \& P. Väisänen (Eds.), TUTKIVA OPETTAJANKOULUTUS- TAITAVA OPETTAJA. Verkkoversio 
2005: Erkki Savolainen ja Kati Ranta. SOKL:n verkkokirjoja. http://sokl.uef. fi/verkkojulkaisut/tutkivaope/sisallys.htm.

OECD. (2012). Perspectives on Global Development 2012: Social Cohesion in a Shifting World. OECD Publishing. https://doi.org/10.1787/persp_ glob_dev-2012-en, http://www.keepeek.com/Digital-Asset-Management/ oecd/development/perspectives-on-global-development-2012_persp_glob_ dev-2012-en\#page 19.

OECD. (2015). Helping Immigrant Students to Succeed at School and Beyond. OECD Publishing. http://www.oecd.org/migration-insights/.

OECD. (2016). Trends Shaping Education 2016. Paris: OECD Publishing. https://doi.org/10.1787/trends_edu-2016-en.

OPH. (2014). National Core Curriculum for Basic Education 2014. Opetushallitus. eBook.

Pettit, J. (2012). Empowerment and Participation: Bridging the Gap Between Understanding and Practice. UNDESA Expert Group Meeting on 10-12 September. New York. http://www.un.org/esa/socdev/egms/docs/2012/ JethroPettit.pdf.

Prato, G. B. (2009). Anthropology at the Intersections Between the Local, the National and the Global. In G. B. Prato (Ed.), Beyond Multiculturalism. Views from Anthropology. Farnham, Surrey: Ashgate.

Putnam, R. D. (2000). Bowling Alone. New York: Simon \& Schuster.

Putnam, R. D. (2001). Social Capital. Measurement and Consequences. Isuma: Canadian Journal of Policy Research, 2(1), 41-51.

Putnam, R. D. (2015). Our Kids. The American Dream in Crisis. New York: Simon \& Schuster.

Ranto, S., Ahlgren-Leinvuo, H., Haapamäki, E., \& Högnabba, S. (2015). Ulkomaalaistaustaisten nuorten hyvinvointi Helsingissä. Tutkimuksia 2015:40. Helsingin kaupunki. Tilastokeskus.

Salmela-Aro, K., Muotka, J., Hakkarainen, K., Alho, K., \& Lonka, K. (2016). School Burnout and Engagement Profiles Among Digital Natives in Finland: A Person-Oriented Approach. European Journal of Developmental Psychology.

Schein, E. H. (1985). Organizational Culture and Leadership. San Francisco, CA: Jossey-Bass.

Stanley, D. (2003). What Do We Know About Social Cohesion. The Research Perspective of the Federal Government's Social Cohesion Network [Special Issue on Social Cohesion in Canada]. The Canadian Journal of Sociology, 28(1), 5-17.

Statistics 2016:2. City Of Helsinki. Urban Facts.

Tikkanen, T. (Ed.). (2014). Helsinki alueittain. Helsinki by districts. Helsinki City Urban facts.

UN DESA. (2012). Perspectives on Social Cohesion-The Glue That Holds Society Together. https://www.un.org/development/desa/en/news/policy/perspectives-on-social-cohesion.html. 
UNESCO. (2014). Policy Paper 14. http://www.uis.unesco.org/Education/ Documents/fs-28-out-of-school-children-en.pdf.

Vilkama, K., Lönnqvist, H., Väliniemi-Laurson, J., \& Tuominen, M. (2014). Erilaistuva pä̈̈kaupunkisentu - sosioekonomiset erot alueittain 2002-2012. Tutkimuksia 2014:1.

Vuori, P., \& Laakso, S. (2015). Helsingin ja Helsingin seudun väestöennuste 2015-2025. Ennuste alueittain 2015-2025. Tilastoja 2015:33. Helsingin kaupunki. Tilastokeskus.

Weingart, P. A. (2010). Short History of Knowledge Formations. In R. Frodemann, J. T. Klein, \& C. Mitcham (Eds.), The Oxford Handbook of Interdisciplinarity (pp. 3-14). Oxford: Oxford University Press.

Zetter, R., Griffiths, D., Sigona, N., Flynn, D., Pasha, T., \& Beynon, R. (2006). Immigrant, Social Cohesion, Social Capita. York: Joseph Rowntree Foundation.

Open Access This chapter is licensed under the terms of the Creative Commons Attribution 4.0 International License (http://creativecommons.org/licenses/ by $/ 4.0 /$ ), which permits use, sharing, adaptation, distribution and reproduction in any medium or format, as long as you give appropriate credit to the original author(s) and the source, provide a link to the Creative Commons license and indicate if changes were made.

The images or other third party material in this chapter are included in the chapter's Creative Commons license, unless indicated otherwise in a credit line to the material. If material is not included in the chapter's Creative Commons license and your intended use is not permitted by statutory regulation or exceeds the permitted use, you will need to obtain permission directly from the copyright holder.

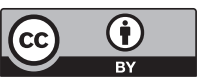

